\title{
RELEASE CHARACTERIZATION AND BIOLOGICAL EFFECT OF GLASS IONOMER FUNCTIONALIZED WITH TWO DIFFERENT CHLOROHEXIDINE DERIVATIVES: "AN IN VITRO STUDY"
}

\author{
Shaimaa M. Abd Ellah*, Mohamed M. Kandil ${ }^{* *}$ and Dina El-Refaie***
}

\begin{abstract}
Aims: To evaluate the effect of adding two different chlorohexidine derivatives; chlorhexidine hexametaphosphate and chlorhexidine digluconate to glass ionomer at three different concentrations $(0.25 \%, 0.75 \%$ and $1.5 \%)$ regarding the antibacterial effect, chlorhexidinerelease and fluoride release.
\end{abstract}

Methods: A total of 405 specimens were prepared and tested after 7 days, 3 months and 6 months of storage in distilled water $(n=5)$.For testing antibacterial effect, chlorhexidine release and fluoride release, the mix was packed in a ready-made Split Teflon molds to obtain disc-shaped specimen with dimensions $10 \mathrm{~mm}$ in diameter and $2 \mathrm{~mm}$ thickness according to ISO standardizations. Oneway ANOVA and One-way repeated measure ANOVA test were used for statistical analysis of data.

Results: The incorporation of chlorhexidine into ChemFil Superior glass ionomer cement in both derivatives has high significance ability to provide a long-term antimicrobial effect on Streptococcus mutans and Lactobacillius acidophilus. The chlorhexidine release was increasedby adding chlorhexidine in both derivatives to GIC than the unmodified Glass-ionomer cement for study duration. However, the fluoride release was decreased in the modified specimens than the original one.

Conclusions: addition of chlorhexidine enhanced the antibacterial effect of the glass ionomer and chlorhexidine release. However, fluoride release was reduced than original

KEYWORD: Glass ionomer cement, chlorhexidine hexametaphosphate, chlorhexidine digluconate, antibacterial effect, streptococcus mutans, lactobacillius acidophilus, fluoride release.

* BDS, Researcher at Biomaterial, Department of Biomaterials, Faculty of Dentistry, Ain-Shams University, organization of African unity St, El-Qobba Bridge, Al Waili, Cairo Governorate, Egypt

** Lecturer of Dental Biomaterials, Department of Biomaterials, Faculty of Dentistry, Ain-Shams University, organization of African Unity St, El-Qobba Bridge, Al Waili, Cairo Governorate, Egypt.

*** Associate professor of Dental Biomaterials, Biomaterials Department, , Faculty of Dentistry, Ain- Shams University, organization of African unity St, El-Qobba Bridge, Al Waili, Cairo Governorate, Egypt. 


\section{INTRODUCTION}

Dental caries is a slow chronic disease that affects the enamel, dentine and cementum. It is characterized by localized destruction of dental hard tissues by acidic by-products released from bacterial fermentation of dietary carbohydrates. ${ }^{(1)}$ Dental caries remains the most common spreader disease worldwide. ${ }^{(2)}$

In the early 1970's, McLean and Wilson developed glass polyalkenoate cement, also known as "glass-ionomer." These cement systems are based on polycarboxylate and silicate materials. The early glass-ionomers offered several advantages for use in children. They were tooth colored, chemically bonded to tooth structure, and released substantial amounts of fluoride for uptake by adjacent tooth structure. ${ }^{(3)}$

Glass-ionomer cement was found to be used efficiently in atraumatic restorative treatment(ART) approach in children rather than other restoration materials because of its adhesion property and on tooth surfaces that have had only minimal preparation. Glass ionomers have been improved by altering particle size and particle size distribution to withstand stresses of mastication; this has improved both compressive strength and physical properties. ${ }^{(4)}$

Resin-modified glass-ionomers (RMGI) were introduce to improve the properties of conventional glass ionomer. Resin modified glass ionomer contains hydrophilic monomers and polymers like HEMA and they have higher flexural strength compared to conventional GIC. ${ }^{(5)}$

Therefore, different trials to modify glass ionomer materials have been introduced to incorporated antimicrobial into restorations to eradicate the bacteria effect and reduce the risk of recurrent caries without negative effects on the properties of restorative materials and the long-term success of restorations ${ }^{(6)}$
Glass ionomer cements leach fluoride into the oral environment. This caused elevation of fluoride concentrations close to the restoration and this may reduce dental caries in the local area owing to the interaction of the fluoride ion with the hydroxyapatite in the enamel and dentine. ${ }^{(7)}$

Chlorhexidine (CHX) is a broad-spectrum antimicrobial with widespread use as a topical agent; because of its antibacterial effects on both grampositive and gram-negative organisms. It antimicrobial properties cause membrane disruption and is efficacious against a wide range of microbes including those implicated in caries cause the inhibition of bacterial accumulation on tooth surfaces. ${ }^{(8)}$

Glass ionomer cement restorative material offers lasting protection against caries. GICs modified with CHX diacetate and CHX digluconate have been reported, and these inhibited growth of Streptococcus mutans and Lactobacillus acidophilus, but there was some deterioration of mechanical properties and the antimicrobial effects were limited to the first 40-90 days of the study, with no bactericidal effect observed after this time. ${ }^{(9)}$

A recent in vitro study found that the addition of $0.5 \%$ chlorhexidine digluconate to GIC resulted in increased antimicrobial properties with no significant effect on the mechanical properties or setting time. However, higher concentrations of chlorhexidine digluconate $(1 \%, 2 \%)$ increased the setting time and decreased the mechanical properties of the GIC. ${ }^{(9)}$

There is development of new chlorhexidine salts formulations to enhance anti-caries effects. Among these salts is sodium hexametaphosphate (NAHMP) which has a strong affinity to the enamel surface because of multiple binding sites, resulting in a reduced mineral loss when associated with fluoride. ${ }^{(10)}$

A study described the use of CHX-HMP as an antimicrobial modification for GICs with solid and viscous paste formulations. The CHX release from the modified cements was prolonged causing long- 
term antibacterial effect; however this modification had adverse effects on the mechanical properties as the particle size, formulations of CHX salt and concentration had an effect on the CHX release profile. ${ }^{(11)}$

The aim of the study was to evaluate the antimicrobial effect of conventional glass ionomer modified by addition of two different chlorhexidine derivatives, at three different concentrations regarding the chlorhexidine release and fluoride release. The addition of chlorhexidine for glass ionomer might had a pronounced and sustained antibacterial effect. Also it might enhance chlorhexidine release and fluoride release.

Sample size calculation was designed to have adequate power to apply a statistical test of the null hypothesis that there is no difference between tested groups. By adopting an alpha level of (0.05) and power $=95 \%$ and an effect size (f) of (0.862), calculations based on the results of TÜRKÜN, L. $\mathrm{S}$, EBNEM, et al. ${ }^{(12)}$; the predicted sample size per group (n) was a total of (5) samples. Sample size calculation was performed using $G^{*}$ Power version 3.1.9.7 ${ }^{(13)}$

\section{MATERIALS AND METHODS}

\section{Materials used in the study}

Materials used in the study, their composition, manufacturers and lot number are shown in table 1 .

\section{Specimens preparation and material testing}

A total of 405 specimens were prepared, 105 specimens for testing of antibacterial effect on streptococcus mutans bacteria, 105 specimens for testing of antibacterial effect on lactobacillius

TABLE (1): Materials used in the study, their composition, manufacturers and lot numbers

\begin{tabular}{|c|c|c|c|c|}
\hline Brand name & Description & Composition & Manufacturer & Lot no. \\
\hline $\begin{array}{l}\text { Glass ionomer } \\
\text { cement GIC }\end{array}$ & $\begin{array}{l}\text { ChemFil }{ }^{\circledR} \text { Superior } \\
\text { Powder/ liquid } \\
\text { GIC }\end{array}$ & $\begin{array}{l}1 \mathrm{~g} \text { powder contains: } 1 .(0.84 \mathrm{~g}) \\
\text { Aluminium-sodium-calcium-fluoro- } \\
\text { phosphoro-silicate (18: } 9: 8: 16: 3: 46) \\
0.84 \mathrm{~g} 2 .(0.15 \mathrm{~g}) \text { Polyacrylic acid (MW } \\
30000-45000) 0.15 \mathrm{~g} \\
\text { Liquid: } 10 \mathrm{ml} \text { demineralized water }\end{array}$ & $\begin{array}{l}\text { DENTSPLY } \\
\text { DeTrey GmbH, } \\
\text { Konstonz, } \\
\text { Germany }\end{array}$ & 1709000428 \\
\hline $\begin{array}{l}\text { Chlorhexidine } \\
\text { digluconate } \\
20 \% \text { aqueous } \\
\text { solution }\end{array}$ & $\begin{array}{l}\text { Colorless or pale yellowish } \\
\text { liquid. It is miscible with } \\
\text { water, soluble in acetone and } \\
\text { in alcohol. The structural } \\
\text { formula: } \mathrm{C} 22 \mathrm{H} 30 \mathrm{Cl} 2 \mathrm{~N} 10 \text {, } \\
2 \mathrm{C} 6 \mathrm{H} 12 \mathrm{O} 7\end{array}$ & $\begin{array}{l}\text { Aqueous sol of chlorhexidine which } \\
\text { cannot be isolated as a solid, } \\
\text { Soluble in water to at least } 50 \%(\mathrm{~W} / \mathrm{V}), \\
\text { with PH range of } 5-8 \text {, density } 1.06 \text { to } 1.07 \\
\text { Melting range between } 132^{\circ} \mathrm{C} \text { TO } 136{ }^{\circ} \mathrm{C}\end{array}$ & $\begin{array}{l}\text { BAJAJ } \\
\text { Healthcare LTD, } \\
\text { Gujarat, } \\
\text { India }\end{array}$ & CS-00400216 \\
\hline $\begin{array}{l}\text { Sodium } \\
\text { hexameta- } \\
\text { phosphate } \\
\text { HMP powder }\end{array}$ & $\begin{array}{l}\text { White crystals, odorless, } \\
\text { hexamer of composition } \\
(\mathrm{NaPO} 2) 2 \text {. Sodium } \\
\text { hexametaphosphate, mixture } \\
\text { of polymeric metaphosphates, } \\
\text { formula: }(\mathrm{NaPO} 3) 6\end{array}$ & $\begin{array}{l}65-70 \% \text { P2O5 basis } \\
\text { Natrium hexametaphoshate, calgon, } \\
\text { phosphate glass, water soluble, } \\
\text { polyphosphate sodium salt, Soluble in } \\
\text { water, Melting range } 628^{\circ} \mathrm{C}\end{array}$ & $\begin{array}{l}\text { Sigma-Aldrich } \\
\text { Co., } \\
\text { St. Louis, MO, } \\
\text { USA) }\end{array}$ & BCBN0343v \\
\hline Distilled water & Purified water USP35 & $50 \mathrm{ml}$ purified water for oral use & $\begin{array}{l}\text { FIPCO, } \\
\text { Borg Elarab, } \\
\text { Alexandria, Egypt }\end{array}$ & $29050 / 2013$ \\
\hline
\end{tabular}


acidophilius bacteria, 105 specimens for fluoride release testing and 90 specimens for chlorhexidine release test. Table 3

Specimens were prepared according to the ISO Guidelines No. 9917-2:2007(E) ${ }^{(14)}$ Materials were proportioned and mixed according to the manufacturers' instructions. The methods of specimen's preparation for each material are summarized in table 2.
After mixing, the material was packed in split Teflon mold to obtain disc-shaped specimen with dimensions $10 \mathrm{~mm}$ in diameter and $2 \mathrm{~mm}$ thickness. The molds were lined with a thin layer of Vaseline to aid in removal of the set cement. The mold was placed on a glass slide then packed with the glass ionomer then another glass slide was placed on top. The cement was compressed between two glass slides and checked for even distribution

TABLE (2) Methods of specimens' preparation for each material

\begin{tabular}{|c|c|c|c|}
\hline $\begin{array}{l}\text { Type of } \\
\text { material }\end{array}$ & Method of specimen's preparation & $\begin{array}{l}\text { Type of } \\
\text { chlorhexidine }\end{array}$ & Method of chlorhexidine application \\
\hline $\begin{array}{l}\text { Conventional } \\
\text { glass ionomer } \\
\text { cement } \\
\text { specimens }\end{array}$ & $\begin{array}{l}\text {-Ratio of } 1 \text { scoop powder: } 1 \text { drop of } \\
\text { liquid was mixed with } \mathrm{P} / \mathrm{L} \text { ratio (wt/ } \\
\text { wt) of } 7.4: 1 \\
\text {-Half the powder was incorporated first } \\
\text { into the liquid as quickly as possible } \\
\text { ( } 5 \text { seconds) and then the remainder was } \\
\text { added and spatulated for } 20 \text { second to } \\
\text { form a thick putty-like consistency. } \\
\text {-Total working time was } 2 \text { minutes. } \\
\text {-Total setting time was } 2-3 \text { minutes. }\end{array}$ & $\begin{array}{l}\text { - no } \\
\text { chlorhexidine } \\
\text { added }\end{array}$ & -no application done. \\
\hline $\begin{array}{l}\text { Glass ionomer } \\
\text { containing } \\
\text { chlorhexidine } \\
\text { digluconate } \\
\text { specimens }\end{array}$ & $\begin{array}{l}\text { Ratio of } 1 \text { scoop powder: } 1 \text { drop } \\
\text { of liquid containing chlorhexidine } \\
\text { digluconate was mixed with } \mathrm{P} / \mathrm{L} \text { ratio } \\
\text { (wt/wt) of } 7.4 \text { : } 1 \\
\text {-Half the powder was incorporated first } \\
\text { into the liquid as quickly as possible } \\
\text { ( } 5 \text { seconds) and then the remainder was } \\
\text { added and spatulated for } 20 \text { second to } \\
\text { form a thick putty-like consistency. } \\
\text {-Total working time was } 2 \text { minutes. } \\
\text {-Total setting time was } 2-3 \text { minutes. }\end{array}$ & $\begin{array}{l}\text { - chlorhexidine } \\
\text { digluconate } \\
\text { liquid }\end{array}$ & $\begin{array}{l}\text {-Chlorhexidine digluconate was added to } \\
\text { the distilled water at concentrations } 0.25 \% \text {, } \\
0.75 \% \text { and } 1.5 \% \text { of CHX digluconate. }\end{array}$ \\
\hline $\begin{array}{l}\text {-Glass ionomer } \\
\text { containing } \\
\text { chlorhexidine } \\
\text { hexametaphosp- } \\
\text { hates specimens }\end{array}$ & $\begin{array}{l}\text {-Ratio of } 1 \text { scoop powder: } 1 \text { drop } \\
\text { of liquid containing chlorhexidine } \\
\text { hexametaphosphate was mixed with } \\
\text { P/L ratio (wt/wt) of } 7.4: 1 \\
\text {-Half the powder was incorporated first } \\
\text { into the liquid as quickly as possible } \\
\text { ( } 5 \text { seconds) and then the remainder was } \\
\text { added and spatulated for } 20 \text { second to } \\
\text { form a thick putty-like consistency. } \\
\text {-Total working time was } 2 \text { minutes. } \\
\text {-Total setting time was } 2-3 \text { minutes. }\end{array}$ & $\begin{array}{l}\text {-chlorhexidine } \\
\text { hexametaphos- } \\
\text { phate powder }\end{array}$ & $\begin{array}{l}\text {-chlorhexidine hexametaphosphate (HMP) } \\
\text { was prepared by mixing aqueous } 10 \mathrm{ml} \\
\text { solutions of CHX digluconate and sodium } \\
\text { HMP in a glass beaker and vigorous stirring } \\
\text { for approximately } 1 \text { min, then the preparation } \\
\text { was allowed to settle for } 24 \text { h to produce a } \\
\text { precipitate. } \\
\text {-The precipitate was filtered from the flask and } \\
\text { discarded leaving a concentrated suspension. } \\
\text { The suspension was centrifuged at } 4760 \mathrm{~g} \\
\text { for } 30 \text { min, and then filtered again to discard } \\
\text { the new precipitate. The remaining paste was } \\
\text { removed from the centrifuge tubes using a } \\
\text { spatula. The paste was added to distilled water } \\
\text { to achieve concentrations of } 0.25 \%, 0.75 \% \\
\text { and } 1.5 \% \text { of CHX hexametaphospahte liquid. }\end{array}$ \\
\hline
\end{tabular}


of the cement. The mixing was completed in 20 seconds and packing into the molds took a further 10 seconds, all manipulation of the cement was completed within $1 \mathrm{~min}$. Specimens were stored in distilled water in an incubator at $37^{\circ}$ for 24 hours before testing.

\section{Antibacterial effect:}

The specimens were put agar petri dish inoculated with Streptococcus mutans and Lactobacillus acidophilus bacterial strains. Petri dish contained BHI agar (per liter: 37g Brain Heart Infusion) and incubated at $37^{\circ} \mathrm{C}$ for $48 \mathrm{~h}$ under anaerobic conditions. Then compacted discs were placed on the inoculated media and keep the inoculated petri dish in the fridge for 2 hours for agar diffusion testing. After 2 hours, transfer the petri dishes to the inoculator at $37{ }^{\circ} \mathrm{C}$ for 24 hours. After the inoculation period, measure the length of inhibition zone for each disc. Specimens $(n=5)$ were tested for time interval (7 days, 3months and 6 months) separately. These groups were prepared for each bacterial species.

\section{Chlorohexidine release:}

The specimens were allowed to set for $30 \mathrm{~min}$ in incubator at $37^{\circ}$ and then immersed in $1 \mathrm{~mL}$ of distilled water. The release profiles for a range of concentrations of $\mathrm{CHX}$ from the cement in the distilled water medium was determined using spectrophotometry. Adsorption of light at wavelength 255 $\mathrm{nm}$ was measured at regular intervals using a spectrophotometer (Hitachi U-1800, Hitachi, Japan) and calibration standards of $5-50 \mathrm{mM} \mathrm{CHX}$ used as references to establish $\mathrm{CHX}$ release from the GICs into the distilled water.

Readings obtained were converted to $\mu$ moles CHX released per unit surface area for each specimen and normalized by subtracting the mean reading for the $0 \%$ substitution, correcting for other eluents of the GIC such as the polyacrylic acid.
A linear relationship between absorbance peak heights obtained from UV-Vis spectrophotometry and the chlorhexidine concentration in the reference solutions were established for each solution.

\section{Fluoride release:}

Specimens were stored in $20 \mathrm{~mL}$ of distilled water at $37^{\circ} \mathrm{C}$ for 7 days. Fluoride ion concentrations were determined in $1 \mathrm{~mL}$ volumes of solution that was removed from the individual sample containers. Fluoride release of each specimen was measured after 7 days, 3months and 6 months using fluoride ion-selective electrode (Orion EA 940, ThermoElectron Corporation, Houston, Texas, USA) attached to an ion meter.

\section{Statistical analysis:}

Numerical data were explored for normality by checking the data distribution, using KolmogorovSmirnov and Shapiro-Wilk tests. Statistical analysis was performed with IBM ${ }^{\circledR}$ SPSS ${ }^{\circledR}$ (SPSS Inc., IBM Corporation, NY, USA), Statistics Version 26 for Windows.

Data showed parametric distribution so; it was represented by mean and standard deviation (SD) values. The significance level was set at $\mathrm{P} \leq 0.05$ within all tests. One-way ANOVA test was used to study the effect of one tested variable and their interaction. Comparison of main and simple effects were done utilizing Bonferroni correction.

One-way repeated measure ANOVA test was conducted to study the effect of time on different tested variables and their interaction. Comparison of main and simple effects were done utilizing Bonferroni correction.

One-way ANOVA followed by pairwise comparisons with Bonferroni correction were used to compare different glass ionomer materials at each time interval and repeated measures ANOVA was used to compare between different time intervals of each material. 
TABLE (3): Factorial design and specimens grouping

\begin{tabular}{|c|c|c|c|c|c|}
\hline \multirow{2}{*}{ Materials } & \multirow{2}{*}{ Groups } & \multirow{2}{*}{ CHX release } & \multirow{2}{*}{$\begin{array}{l}\text { Fluoride } \\
\text { release }\end{array}$} & \multicolumn{2}{|c|}{ Antibacterial effect } \\
\hline & & & & streptococcus & lactobacillus \\
\hline \multirow{4}{*}{$\begin{array}{c}\text { Conventional } \\
\text { Glass ionomer (GIC) }\end{array}$} & immediate & - & - & - & - \\
\hline & 7days & - & 5 & 5 & 5 \\
\hline & 3 months & - & 5 & 5 & 5 \\
\hline & 6 months & - & 5 & 5 & 5 \\
\hline \multirow{4}{*}{ GIC - CHX HMP $0.25 \%$} & immediate & - & - & - & - \\
\hline & 7days & 5 & 5 & 5 & 5 \\
\hline & 3 months & 5 & 5 & 5 & 5 \\
\hline & 6 months & 5 & 5 & 5 & 5 \\
\hline \multirow{4}{*}{$\begin{array}{c}\text { GIC - CHX HMP of conc. } \\
0.75 \%\end{array}$} & immediate & - & - & - & - \\
\hline & 7days & 5 & 5 & 5 & 5 \\
\hline & 3 months & 5 & 5 & 5 & 5 \\
\hline & 6 months & 5 & 5 & 5 & 5 \\
\hline \multirow{4}{*}{$\begin{array}{c}\text { GIC - CHX HMP of conc. } \\
1.5 \%\end{array}$} & immediate & - & - & - & - \\
\hline & 7days & 5 & 5 & 5 & 5 \\
\hline & 3 months & 5 & 5 & 5 & 5 \\
\hline & 6 months & 5 & 5 & 5 & 5 \\
\hline \multirow{4}{*}{$\begin{array}{c}\text { GIC-CHXdigluconate conc. } \\
0.25 \%\end{array}$} & immediate & - & - & - & - \\
\hline & 7days & 5 & 5 & 5 & 5 \\
\hline & 3 months & 5 & 5 & 5 & 5 \\
\hline & 6 months & 5 & 5 & 5 & 5 \\
\hline \multirow{4}{*}{$\begin{array}{l}\text { GIC- CHXdigluconate conc. } \\
\qquad 0.75 \%\end{array}$} & immediate & - & - & - & - \\
\hline & 7days & 5 & 5 & 5 & 5 \\
\hline & 3 months & 5 & 5 & 5 & 5 \\
\hline & 6 months & 5 & 5 & 5 & 5 \\
\hline \multirow{4}{*}{$\begin{array}{l}\text { GIC- CHXdigluconate conc. } \\
1.5 \%\end{array}$} & immediate & - & - & - & - \\
\hline & 7days & 5 & 5 & 5 & 5 \\
\hline & 3 months & 5 & 5 & 5 & 5 \\
\hline & 6 months & 5 & 5 & 5 & 5 \\
\hline Total & & & & & \\
\hline
\end{tabular}




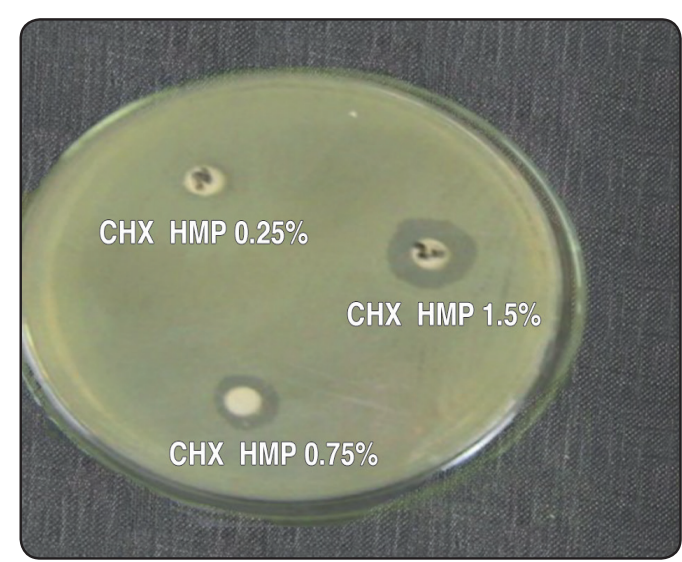

Image (1): Antibacterial effect of GIC containing chlorhexidine hexaametaphosphate of different conc. after 6 months

\section{RESULTS}

\section{Antibacterial effect results:}

For antibacterial effect test, inhibition zones against streptococcus mutans was tested for different groups after 7 days, 3 months and 6 months. The difference between all the groups and the control was significant $(\mathrm{p}<0.05)$. The largest inhibition zones values was after 7 days, followed by 3 months than 6 months. For GICS containing chlorhexidine hexametaphoshate revealed to have statically significant values higher than GIC containing digluconate through the time interval and concentration of $1.5 \%$ showed the largest inhibition zones in all time for both derivatives. Table 4. Fig 1

For lactobacillus acidophilus test, the difference between the groups was also significant while compared with the control $(\mathrm{p}<0.05)$. Inhibition zones against was tested for different groups after 7 days, 3 months and 6 months. The largest inhibition zones values were after 7 days, followed by 3 months than 6 months. For GICS containing chlorhexidine hexametaphoshate were revealed to have statically significant values higher than GIC containing digluconate through the time interval and concentration of $1.5 \%$ showed the largest inhibition zones $(\mathrm{mm})$ in all time for both derivatives. Table 5. Fig 2

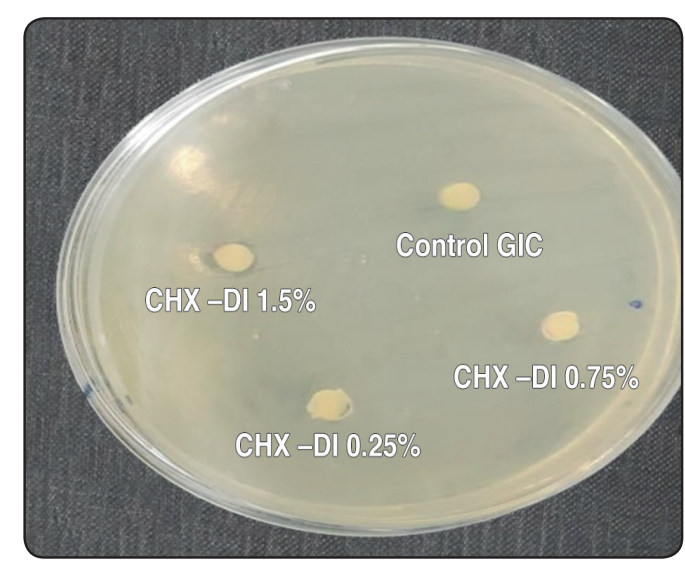

Image (2): Antibacterial effect of GIC containing chlorhexidine digluconate of different conc. after 6 months

\section{Chlorhexidine release results:}

For 7 days' groups, GIC containing chlorhexidine derivatives were revealed to have statically significant higher values of release than unmodified GIC.After 3 months, GICS containing chlorhexidine hexametaphoshate revealed to have statically significant values higher than GIC containing digluconate and unmodified GIC. After 6 months, GIC containing chlorhexidine hexametaphoshate revealed to have statically significant values higher than GIC containing digluconate and unmodified GIC, concentration of $1.5 \%$ showed the highest chlorhexidine release. For the Means and standard deviations (SD) for chlorhexidine release $(\mu \mathrm{g} / \mathrm{ml})$ of the different tested materials with time are presented in Table 6. Fig 3

\section{Fluoride release results:}

Unmodified GICs showed highest value of fluoride release than other concentration showed lower values with significant differences between them and the control GICs time interval of the study (7 days, 3 months and 6 months) for the Means and standard deviations (SD) for fluoride release (ppm)of the different tested materials with time are presented in Table 7. Fig 4 
TABLE (3):Summary table for Mean \pm standard deviation (SD) of antibacterial effect $(\mathrm{mm})$ of inhibition zones of streptococcus mutans for different measurement times and concentrations of different chlorohexidine derivatives

\begin{tabular}{|c|c|c|c|c|}
\hline \multirow{2}{*}{$\begin{array}{l}\text { Concentration of different } \\
\text { chlorohexidine derivatives }\end{array}$} & \multicolumn{3}{|c|}{ Time of measurement $($ mean \pm SD $)$} & \multirow{2}{*}{ p-value } \\
\hline & 7 days & 3 months & 6 months & \\
\hline (GIC) & $24.00 \pm 5.48^{\mathrm{Ba}}$ & $4.40 \pm 6.02^{\mathrm{Db}}$ & $0.00 \pm 0.00^{\mathrm{Db}}$ & $<0.001^{*}$ \\
\hline (GIC HMP0.25\%) & $46.00 \pm 4.18^{\mathrm{Aa}}$ & $24.00 \pm 4.18^{\mathrm{Bb}}$ & $13.20 \pm 1.30^{\mathrm{Cc}}$ & $<0.001^{*}$ \\
\hline (GIC HMP0.75\%) & $47.00 \pm 4.47^{\mathrm{Aa}}$ & $28.00 \pm 2.74^{\mathrm{Bb}}$ & $16.20 \pm 0.84^{\mathrm{Bc}}$ & $<0.001^{*}$ \\
\hline (GIC HMP $1.5 \%$ ) & $54.00 \pm 5.48^{\mathrm{Aa}}$ & $38.00 \pm 2.74^{\mathrm{Ab}}$ & $17.60 \pm 0.55^{\mathrm{Ac}}$ & $<0.001 *$ \\
\hline (GIC DI $0.25 \%)$ & $28.00 \pm 2.74^{\mathrm{Ba}}$ & $6.60 \pm 6.02^{\mathrm{Db}}$ & $0.00 \pm 0.00^{\mathrm{Db}}$ & $<0.001 *$ \\
\hline (GIC DI $0.75 \%)$ & $46.00 \pm 4.18^{\mathrm{Aa}}$ & $14.60 \pm 0.55^{\mathrm{Cb}}$ & $0.00 \pm 0.00^{\mathrm{Dc}}$ & $<0.001^{*}$ \\
\hline (GIC DI $1.5 \%)$ & $50.00 \pm 6.12^{\mathrm{Aa}}$ & $14.60 \pm 0.55^{\mathrm{Cb}}$ & $0.00 \pm 0.00^{\mathrm{Dc}}$ & $<0.001^{*}$ \\
\hline p-value & $<0.001 *$ & $<0.001 *$ & $<0.001 *$ & \\
\hline
\end{tabular}

Different upper and lowercase superscript letters indicate a statistically significant difference within the same vertical column or horizontal row respectively*; significant $(p \leq 0.05) n$ s; non-significant $(p>0.05)$

TABLE (4): Summary table: Mean \pm standard deviation (SD) of antibacterial effect $(\mathrm{mm})$ of inhibition zones of lactobacillus acidophilus for different measurement times and concentrations of different chlorohexidine derivatives

\begin{tabular}{|c|c|c|c|c|}
\hline \multirow{2}{*}{$\begin{array}{c}\text { Concentration of different } \\
\text { chlorohexidine derivatives }\end{array}$} & \multicolumn{3}{|c|}{ Time of measurement (mean \pm SD) } & \multirow{2}{*}{ p-value } \\
\cline { 2 - 5 }$($ GIC) & $\mathbf{7}$ days & $\mathbf{3}$ months & $\mathbf{6}$ months & $<0.001 *$ \\
\hline$($ GIC HMP 0.25\%) & $39.00 \pm 7.42^{\mathrm{BCa}}$ & $22.00 \pm 4.47^{\mathrm{Bb}}$ & $11.40 \pm 0.55^{\mathrm{Cc}}$ & $<\mathbf{0 . 0 0 1 *}$ \\
\hline$($ GIC HMP 0.75\%) & $44.00 \pm 5.48^{\mathrm{Aba}}$ & $25.00 \pm 3.54^{\mathrm{ABb}}$ & $14.40 \pm 0.55^{\mathrm{Bc}}$ & $<\mathbf{0 . 0 0 1 *}$ \\
\hline$($ GIC HMP 1.5\%) & $54.00 \pm 5.48^{\mathrm{Aa}}$ & $35.00 \pm 5.00^{\mathrm{Ab}}$ & $16.40 \pm 0.55^{\mathrm{Ac}}$ & $<\mathbf{0 . 0 0 1 *}$ \\
\hline$($ GIC DI 0.25\%) & $28.00 \pm 2.74^{\mathrm{CDa}}$ & $6.60 \pm 6.02^{\mathrm{Cb}}$ & $0.00 \pm 0.00^{\mathrm{Db}}$ & $<\mathbf{0 . 0 0 1 *}$ \\
\hline$($ GIC DI 0.75\%) & $46.00 \pm 4.18^{\mathrm{Aba}}$ & $7.00 \pm 6.40^{\mathrm{Cb}}$ & $0.00 \pm 0.00^{\mathrm{Db}}$ & $<\mathbf{0 . 0 0 1 *}$ \\
\hline$($ GIC DI 1.5\%) & $52.00 \pm 7.58^{\mathrm{Aa}}$ & $7.00 \pm 6.40^{\mathrm{Cb}}$ & $0.00 \pm 0.00^{\mathrm{Db}}$ & $<\mathbf{0 . 0 0 1 *}$ \\
\hline p-value & $<\mathbf{0 . 0 0 1 *}$ & $<\mathbf{0 . 0 0 1 *}$ & $<\mathbf{0 0 0 1 *}$ & \\
\hline
\end{tabular}

Different upper and lowercase superscript letters indicate a statistically significant difference within the same vertical column or horizontal row respectively*; significant $(p \leq 0.05) n s ;$ non-significant $(p>0.05)$. 
TABLE (5): Summary table: Mean \pm standard deviation (SD) of chlorohexidine release $(\mu \mathrm{g} / \mathrm{ml})$ for different measurement times and concentrations of different chlorohexidine derivatives

\begin{tabular}{|c|c|c|c|c|}
\hline \multirow{2}{*}{$\begin{array}{c}\text { Concentration of different } \\
\text { chlorohexidine derivatives }\end{array}$} & \multicolumn{3}{|c|}{ Time of measurement (mean \pm SD) } & \multirow{2}{*}{ p-value } \\
\cline { 2 - 5 } & $\mathbf{7}$ days & $\mathbf{3}$ months & $\mathbf{6}$ months & $0.01 \pm 0.00^{\mathrm{Da}}$ \\
\hline$($ GIC) & $0.06 \pm 0.03^{\mathrm{Da}}$ & $0.01 \pm 0.00^{\mathrm{Ea}}$ & $0.83 \pm 0.09^{\mathrm{Cb}}$ & $<\mathbf{0 . 0 0 1} *$ \\
\hline$($ GIC HMP 0.25\%) & $2.85 \pm 0.47^{\mathrm{Ca}}$ & $1.87 \pm 0.58^{\mathrm{BCab}}$ & $1.25 \pm 0.21^{\mathrm{Bc}}$ & $<\mathbf{0 . 0 0 1} *$ \\
\hline$($ GIC HMP $1.5 \%)$ & $4.09 \pm 0.59^{\mathrm{Ba}}$ & $2.50 \pm 0.36^{\mathrm{Bb}}$ & $1.84 \pm 0.41^{\mathrm{Ac}}$ & $<\mathbf{0 . 0 0 1} *$ \\
\hline$($ GIC DI 0.25\%) & $5.91 \pm 0.34^{\mathrm{Aa}}$ & $3.41 \pm 0.43^{\mathrm{Ab}}$ & $0.01 \pm 0.01^{\mathrm{Dc}}$ & $<\mathbf{0 . 0 0 1} *$ \\
\hline$($ GIC DI 0.75\%) & $3.14 \pm 0.36^{\mathrm{Ca}}$ & $0.89 \pm 0.08^{\mathrm{Db}}$ & $0.01 \pm 0.01^{\mathrm{Dc}}$ & $<\mathbf{0 . 0 0 1 *}$ \\
\hline$($ GIC DI 1.5\%) & $4.07 \pm 0.64^{\mathrm{Ba}}$ & $1.90 \pm 0.61^{\mathrm{BCb}}$ & $0.04 \pm 0.03^{\mathrm{Dc}}$ & $<\mathbf{0 . 0 0 1} *$ \\
\hline p-value & $4.68 \pm 0.38^{\mathrm{Ba}}$ & $1.25 \pm 0.23^{\mathrm{CDb}}$ & $<\mathbf{0 . 0 0 1 *}$ & \\
\hline
\end{tabular}

Different upper and lowercase superscript letters indicate a statistically significant difference within the same vertical column or horizontal row respectively*; significant $(p \leq 0.05)$ ns; non-significant $(p>0.05)$

TABLE (6):Summary table Mean \pm standard deviation (SD) of fluoride release (ppm) for different measurement times and concentrations of different chlorohexidine derivatives

\begin{tabular}{|c|c|c|c|c|}
\hline \multirow{2}{*}{$\begin{array}{l}\text { Concentration of different } \\
\text { chlorohexidine derivatives }\end{array}$} & \multicolumn{3}{|c|}{ Time of measurement $($ mean \pm SD) } & \multirow{2}{*}{ p-value } \\
\hline & 7 days & 3 months & 6 months & \\
\hline (GIC) & $7.90 \pm 0.72^{\mathrm{Aa}}$ & $1.96 \pm 0.45^{\mathrm{Ab}}$ & $0.66 \pm 0.35^{\mathrm{Ac}}$ & $<0.001 *$ \\
\hline (GIC HMP $0.25 \%)$ & $4.32 \pm 1.42^{\mathrm{CDa}}$ & $1.31 \pm 0.18^{\mathrm{Bb}}$ & $0.45 \pm 0.27^{\mathrm{ABc}}$ & $<0.001 *$ \\
\hline (GIC HMP 0.75\%) & $3.09 \pm 0.62^{\mathrm{Da}}$ & $1.06 \pm 0.05^{\mathrm{Bb}}$ & $0.18 \pm 0.11^{\mathrm{Bc}}$ & $<0.001 *$ \\
\hline (GIC HMP $1.5 \%)$ & $4.11 \pm 0.56^{\mathrm{CDa}}$ & $1.08 \pm 0.07^{\mathrm{Bb}}$ & $0.17 \pm 0.05^{\mathrm{Bc}}$ & $<0.001 *$ \\
\hline (GIC DI $0.25 \%)$ & $6.35 \pm 0.80^{\mathrm{ABa}}$ & $1.91 \pm 0.37^{\mathrm{Ab}}$ & $0.56 \pm 0.23^{\mathrm{ABc}}$ & $<0.001 *$ \\
\hline (GIC DI $0.75 \%)$ & $4.93 \pm 1.11^{\mathrm{BCa}}$ & $1.22 \pm 0.12^{\mathrm{Bb}}$ & $0.44 \pm 0.08^{\mathrm{ABc}}$ & $<0.001 *$ \\
\hline (GIC DI 1.5\%) & $4.20 \pm 0.76^{\mathrm{CDa}}$ & $1.10 \pm 0.09^{\mathrm{Bb}}$ & $0.18 \pm 0.13^{\mathrm{Bc}}$ & $<0.001 *$ \\
\hline p-value & $<0.001 *$ & $<0.001 *$ & $<0.001 *$ & \\
\hline
\end{tabular}

Different upper and lowercase superscript letters indicate a statistically significant difference within the same vertical column or horizontal row respectively*; significant $(p \leq 0.05)$ ns; non-significant $(p>0.05)$ 


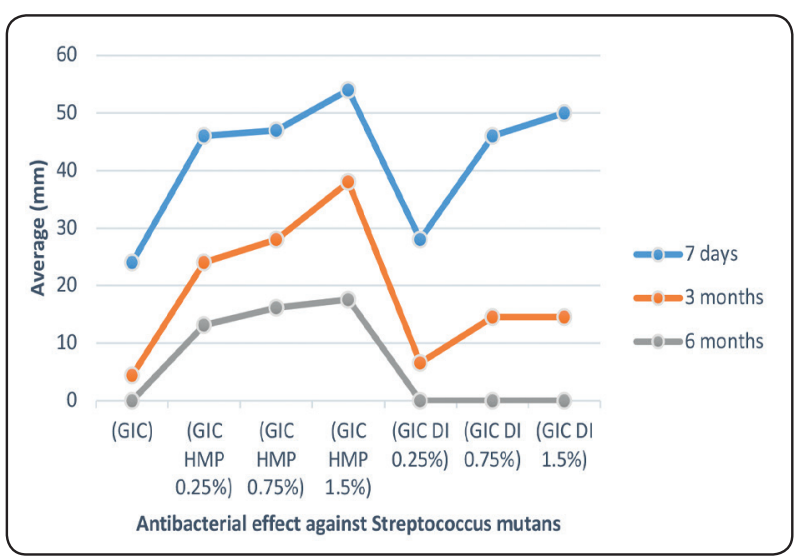

Fig. (1): Line chart showing average antibacterial effect (mm) of inhibition zones against streptococcus mutansfor different measurement times and concentrations of different chlorohexidine derivative.

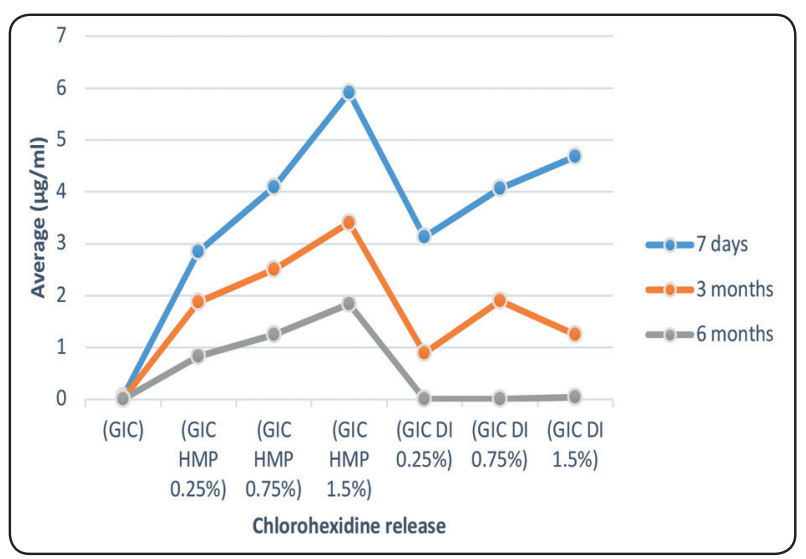

Fig. (3): Line chart showing average chlorohexidine release $(\mu \mathrm{g} /$ $\mathrm{ml}$ ) for different measurement times and concentrations of different chlorohexidine derivatives.

\section{DISCUSSION}

The concept of controlled-release therapeutic systems as in GIC-CHX to deliver a predetermined amount of CHX for a specific period is of concern to improve their clinical efficacy and increase their antimicrobial efficacy. ${ }^{(15)}$

Results of agar diffusion test showed that the sizes of inhibition zones produced against $\mathrm{S}$. mutans and L. acidophilus were dependent upon the concentration of the $\mathrm{CHX}$ incorporated to the GIC in all tested groups. This is due to higher concentrations are direct proportion to the presence

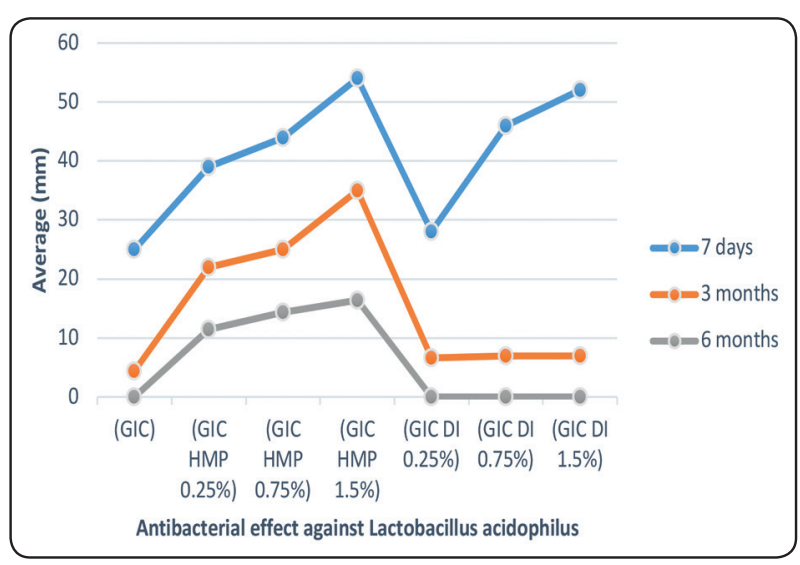

Fig. (2): Line chart showing average antibacterial effect (mm) of inhibition zones of lactobacillus acidophilus for different measurement times and concentrations of different chlorohexidine derivatives.

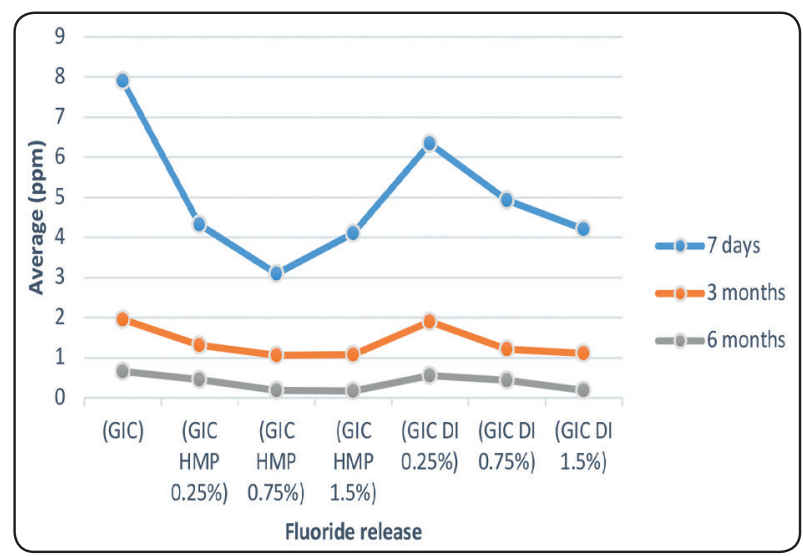

Figure (4): Line chart showing average fluoride release (ppm) for different measurement times and concentrations of different chlorohexidine derivatives.

of large amount of soluble CHX in the elution medium that cause antibacterial effect. The highest results were recorded in CHX-HMP GIC $1.5 \%$ conc. antibacterial effect in all specimens. ${ }^{(16)}$

This is in agreement with Botelho et al. studies showed that the antibacterial-GIC combination specimens showed significant inhibition zones, which increased with the CHX concentrations. ${ }^{(17)}$

It was found that the inhibition zone decrease in size during the duration of the study in all the specimens. The inhibition zone was the largest in agar plates after 7 days in all specimens then fades 
out by the time of the study. CHX digluconate specimens showed decrease in size of inhibition zone after 3 months while the CHX-HMP effect was noticed for longer duration 6 months.

This is in agreement with Bellis.A et al who found that CHX-HMP cements exhibited a sustained release of soluble CHX over one year and was capable of inhibiting the growth of oral pathogens in vitro. ${ }^{(13)}$

This is also in agreement with Hook et al. who found that the CHX release from digluconate derivatives shown that an antimicrobial effect persisted for between 40 and 90 days. ${ }^{(18)}$

In literature, Chlorhexidine was added to different salts like diacetate, digluconate, dichloride and hexametaphosphate as a releasing molecule. In this study, CHX was added to GIC using digluconate and hexametaphosphate to compare the substantivity duration.

CHX digluconate specimens showed decrease in size of inhibition zone after 3 months while the CHX-HMP effect was noticed for longer duration 6 months

Recent studies showed that hexametaphosphate as a large molecule can cause slow release of CHX than other salts. Large clusters of CHX-HMP particles, which were formed during the production process, could cause CHX release for longer duration. CHX was probed over a clinically relevant timescale of over one year. ${ }^{(13)}$

Results of agar diffusion test showed that the sizes of inhibition zones produced against $\mathrm{S}$. mutans and L. acidophilus were dependent upon the concentration of the CHX incorporated to the GIC in all tested groups. This could be attributed to the fact that higher concentrations are direct proportion to the presence of large amount of soluble CHX in the elution medium, that cause an antibacterial effect. The highest results were recorded in CHX-HMP GIC $1.5 \%$ conc. antibacterial effect in all specimen

This is in agreement with De Castilho et al. who found that the antibacterial effect was concentrationdependent,since higher concentrations produced larger inhibition zones. ${ }^{(19)}$

Also, Ribeiro ${ }^{(20)}$ et al. and Botelho ${ }^{(17)}$ et al.studies' showed that the antibacterial-GIC combination specimens showed significant inhibition zones which increased with the CHX concentrations.

For all concentration in both derivatives, the highest $\mathrm{CHX}$ release was after 7 days, then there was a decrease in the CHX release after 3 months. The lowest CHX release values was recorded after 6 months. GIC containing digluconate did not release any chlorhexidine after 6 months. This may be due formation of large clusters of CHX-HMP particles, which were formed during the incorporation of HMP in CHX. The hexametaphosphate salt, which is a large molecule, has low solubility compared to the digluconate compound, thus allow slow and sustained release of CHX than the digluconate salt

This is in agreement with Bellis.A et al who stated that the release pattern of chlorhexidine depends on the concentrations and the chemistry of different $\mathrm{CHX}$ compounds. The higher conc. of CHX-HMP, disrupt the setting process of the GIC, cause the GIC to become more porous and release more. ${ }^{(13)}$

This is also in agreement with Hook et al. who found that the CHX release from digluconate derivatives shown that an antimicrobial effect persisted for between 40 and 90 days. ${ }^{(19)}$

For fluoride release testing, results showed that the unmodified GIC's release more fluoride than the GIC containing CHX derivatives. This might be explained by the interaction between fluoride and the cationic CHX molecule, resulting in the precipitation of salts with lower solubility, leaving fluoride less available in GIC containing CHX derivatives. ${ }^{(22)}$

Also fluoride released from CHX-digluconate is more than that released from CHX-HMP. This might be due to the hexametaphosphate molecule, 
which is a complex molecule capable of bonding with fluoride. This makes its release to be lower than other derivatives and also lower than the unmodified specimens. ${ }^{(18)}$

The initial fluoride release rate from glass ionomer was rapid initially and then gradually slowed over the experimental period. Fluoride release decrease with time but remain measurable after 60 days. ${ }^{(22)}$ This may be due to high instability and erosion of GICs during the early setting period, followed by a rapid decrease in the rate of release. ${ }^{(23)}$

This is in agreement with Kucukyilmaz et al. who concluded that GICs had the greatest amount of fluoride ions on the 1stday. Fluoride continued to be released in relatively low amounts from day 2 until day 49. The high level of fluoride release from GIC materials on the first day was due to an initial "burst" of fluoride release from the glass particles during the setting reaction and the rapid dissolution of fluoride from the outer surface into the solution. The slower release of fluoride during next days happened due to the slower dissolution of glass particles through cement pores. ${ }^{23)}$

\section{CONCLUSIONS}

- The incorporation of CHX into glass ionomer cement in both derivatives has the ability to provide a long-term antimicrobial effect on $\mathrm{S}$. mutans and L. acidophilus.

- The substantivity of CHX released was dependent on the molecule attached to in the cement either digluconate or hexametaphosphate in duration of release.

- Fluoride release of GIC decrease by adding CHX in both derivatives and with the increase of concentrations

\section{FUNDING}

This research did not receive any specific grant from funding agencies in the public, commercial, or not-for-profit sectors.

\section{REFERENCES}

1. Selwitz RH, Ismail AI, Pitts NB. Dental caries. The Lancet. 2007;369(9555):51-9.

2. Philip N, Suneja B, Walsh L. Beyond Streptococcus mutans: clinical implications of the evolving dental caries aetiological paradigms and its associated microbiome. British dental journal. 2018;224(4):219

3. Croll TP, Berg JH. Resin-modified glass-ionomer restoration of primary molars with proximating Class II caries lesions. Compendium of continuing education in dentistry (Jamesburg, NJ: 1995). 2007;28(7):372-6; quiz 7, 86.

4. Frencken J, Van't Hof M, Van Amerongen W, Holmgren C. Effectiveness of single-surface ART restorations in the permanent dentition: a meta-analysis. Journal of dental research. 2004;83(2):120-3.

5. Nagaraja Upadhya P, Kishore G. Glass ionomer cement: The different generations. Trends Biomater Artif Organs. 2005;18(2):158-65.

6. Takahashi N, Nyvad B. The role of bacteria in the caries process: ecological perspectives. Journal of dental research. 2011;90(3):294-303

7. Wiegand A, Buchalla W, Attin T. Review on fluoride-releasing restorative materials - fluoride release and uptake characteristics, antibacterial activity and influence on caries formation. Dental materials. 2007;23(3):343-62.

8. Bhola SM, Kundu S, Alabbas F, Mishra B, Olson DL. An electrochemical study on chlorhexidine gluconate addition to normal saline for oral implant applications. Int J Electrochem Sci. 2013;8:5172-82.

9. TÜRKÜN LSE, TÜRKÜN M, ERTUG $\breve{R}$ RU F, Ates M, Brugger S. Long-term antibacterial effects and physical properties of a chlorhexidine-containing glass ionomer cement. Journal of Esthetic and Restorative Dentistry. 2008;20(1):29-44

10. Da Camara DM, Pessan JP, Francati TM, Souza JAS Danelon M, Delbem ACB. Fluoride toothpaste supplemented with sodium hexametaphosphate reduces enamel demineralization in vitro. Clinical oral investigations. 2016;20(8):1981-5.

11. Bellis CA, Nobbs AH, O’Sullivan DJ, Holder JA, Barbour ME. Glass ionomer cements functionalised with a concentrated paste of chlorhexidine hexametaphosphate provides dose-dependent chlorhexidine release over at least 14 months. Journal of dentistry. 2016;45:53-8 
12. TÜRKÜN, L. S, EBNEM, et al. "Long-term antibacterial effects and physical properties of a chlorhexidinecontaining glass ionomer cement." Journal of Esthetic and Restorative Dentistry 20.1 (2008): 29-44.

13. Faul, Franz, et al. "G* Power 3: A flexible statistical power analysis program for the social, behavioral, and biomedical sciences.” Behavior research methods 39.2 (2007): 175-191.

14. ISO I. 9917-2: dentistry-water-based cements-part 2: resin-modified cements. Geneva, Switzerland: International Organization for Standardization. 2010.

15. Farret MM, de Lima EM, Mota EG, Oshima HM, Barth V, De Oliveira SD. Can we add chlorhexidine into glass ionomer cements for band cementation? The Angle Orthodontist. 2011;81(3):496-502.

16. De Castilho ARF, Duque C, de Cássia Negrini T, Sacono NT, De Paula AB, de Souza Costa CA, et al. In vitro and in vivo investigation of the biological and mechanical behaviour of resin-modified glass-ionomer cement containing chlorhexidine. Journal of dentistry. 2013;41(2):155-63.

17. Botelho MG. Inhibitory effects on selected oral bacteria of antibacterial agents incorporated in a glass ionomer cement. Caries research. 2003;37(2):108-14.

18. Hook ER, Owen OJ, Bellis CA, Holder JA, O'Sullivan
DJ, Barbour ME. Development of a novel antimicrobialreleasing glass ionomer cement functionalized with chlorhexidine hexametaphosphate nanoparticles. Journal of nanobiotechnology. 2014;12(1):3.

19. De Castilho ARF, Duque C, de Cássia Negrini T, Sacono NT, De Paula AB, de Souza Costa CA, et al. In vitro and in vivo investigation of the biological and mechanical behaviour of resin-modified glass-ionomer cement containing chlorhexidine. Journal of dentistry. 2013; 41(2):155-63.

20. Ribeiro J, Ericson D. In vitro antibacterial effect of chlorhexidine added to glass-ionomer cements. European Journal of Oral Sciences. 1991;99(6):533-40.

21. Elgamily H, Ghallab O, El-Sayed H, Nasr M. Antibacterial potency and fluoride release of a glass ionomer restorative material containing different concentrations of natural and chemical products: An in-vitro comparative study. Journal of clinical and experimental dentistry. 2018;10(4):e312.

22. Hoszek A, Ericson D. In vitro fluoride release and the antibacterial effect of glass ionomers containing chlorhexidine gluconate. Operative dentistry. 2008; 33(6):696-701.

23. Kucukyilmaz E, Savas S, Kavrik F, Yasa B, Botsali M. Fluoride release/recharging ability and bond strength of glass ionomer cements to sound and caries-affected dentin. Nigerian journal of clinical practice. 2017;20(2):226-34. 